\title{
The Long Years of Military Rule in Nigeria: A Blessing or a Curse
}

\author{
ETEBOM John Monday, PhD \\ Department of Local Government and Development Studies \\ Faculty of Administration \\ Obafemi Awolowo University, Ile-Ife.
}

Received: Feb. 18, 2021 Accepted: Mar. 17, 2021 Online published: Apr. 9, 2021

doi:10.5296/jpag.v11i2.18355 URL: https://doi.org/10.5296/jpag.v11i2.18355

\begin{abstract}
Nigeria gained her independence in October 1960 after almost six decades of British colonial rule. The country's journey into nationhood was herald by high hopes and prospects for national unity, peace and development. This was because of its vast human and material resources, and land mass. Nigeria is dominantly made of three prominent regions: the North (Hausa Fulani), the West (Yorubas) and the East (Igbos) with minorities in other regions.

The military took over the leadership of the country barely six years into her independence as a nation. The military held sway for twenty nine years out of the ininitial forty years of the country's post independence history before her return to civil rule in 1999.

The county is still been confronted with challenges on all fronts ranging from insecurity and insurgency, economy, political uncertainty, electoral malpractices, high rate of unemployment, poor infrastructure amongst others. Literature have been skewed toward military intervention in politics as the root cause of the challenges bedeviling the country more than two decades after her return to civil rule.

The study employed both quantitative and qualitative data. The study analysed the history of military rule in Nigeria and interrogated the crux of the military institution. It further analysed the peculiarities of each of the military regimes. The study also examined the post-military era in the country and concluded with recommendations.
\end{abstract}

Keywords: military, coup, fourth republic, colonialism and corruption

\section{Introduction}

It is impossible to give a recount of Nigerian history without making prominent reference to the role of the military in her colonial experience, as well as her struggle for independence 
and her post-independence experience. Nigeria is one of the most populated countries in sub-Saharan Africa with an estimated population of 200 million. She gained her independence in 1960, after about 60 years under the British colonial rule. The country's journey to nationhood was heralded by high hopes and development prospects having discovered crude oil in 1954. More so, Nigeria is endowed with high human and vast material resources across the country. Unfortunately, almost 60 years of her post-independence history, Nigeria has remained a third-world country struggling with developing problems ranging from democratic consolidation to political uncertainty, insecurity and insurgency, ethnic agitation, poor infrastructural development, high rate of poverty and unemployment, among others.

Some scholars, political elites and citizens have continued to blame the military as the cause of the challenges contending with national development and integration (Ekeh, 1998; Agagu $\&$ Ola, 2011). They argue that the military's intervention in the country's politics shortly after independence and its long years and style of governance of almost three decades are largely responsible for the problems bedevilling the country. Contrarily, some scholars argue that the military as a governmental institution left some gains for the country despite its undemocratic rule (Fawole, interview 2019, Adekanye, 2003).

It is interesting to note that the role of the military in Nigerian politics has been a recurring discourse among scholars, the political and governing elites, the military and citizens even after two decades of post-military rule in the country.

The phenomenon of military rule in politics did not begin in Nigeria although it is now considered a thing of the past because the military's involvement in politics is regarded as an aberration and undemocratic. Most third world countries in Africa, Asia and Latin America have had their share of military rule. However, the consequent impact of military rule on the Nigerian political scene has continued to generate debates owing to its long stay in power, the involvement of retired military officers in post-military rule and the country's inability to consolidate her democracy after two decades of uninterrupted democratic experience.

Military intervention in Nigerian politics dates back to the colonial era. The country's first Governor-General, Lord Lugard, was a British military officer. He was responsible for the amalgamation of the Lagos Colony, the Northern and the Southern Protectorates into a single entity named Nigeria by his wife. Further still, the military took over the political leadership of the country through a bloody coup on 15 January, 1966, barely six years into her post-colonial experience. The military ruled the country at the first instance from 15 January, 1966 , to 1 October, 1979 . The military returned, in what is commonly referred to as the second coming of the military in Nigerian politics, on 31 December, 1983 till 29 May, 1999 when the country returned to democratic rule.

For almost 30 years out of the first 39 years of her post-independence history, the military was in charge of the leadership of the country. These long years of the military participation in the Nigerian politics has made the debate of its role and impact ever relevant in the country's quest for development, integration and democratic consolidation. There were eleven coups, both successful and otherwise, within this period in Nigerian history. Ekeh 
(1998) argues that it will be naive to believe that the mere act of holding elections will usher in a new era of freedom for the country after three decades of military dictatorship. He further mentions that these decades have left behind an infamy curse that Nigeria will wrestle with for years and possibly decades to come. It may not be absolutely correct to say the long years of military rule in the country were either a curse or a blessing because every system of government usually has its merits and demerits.

This study empirically examined the history, role and impact of the military rule in Nigeria by analysing the various military regimes as against the general judgmental submission of military rule in the country. This was carried out through a critical analysis of the circumstances that heralded their emergence in government, the peculiarities in the style of governance, that is, foreign policies, economy, developments, human rights, national security, among others. It explored further the linkage between the peculiarities of each regime and its impact on Nigerian politics from independence till date. It concluded with policy recommendations. It is important to mention that the activities of each regime analyzed in the study are major highlights, and not necessarily the totality of their activities. The study employed qualitative and quantitative methods of data collection and also drew from the benefit of insight of the researcher, who after having served in the military for almost a decade as a soldier is now a political scientist.

\section{The Military in Nigerian Politics}

The history of military intervention in Nigerian politics is usually traced to January, 1966 coup d'état. In fact, military invention in Nigeria can be said to be as old as the Nigerian state itself. It can be traced to 1914 when the first colonial Governor General, Colonel Lord Lugard, a British Army Officer, amalgamated the Northern and Southern protectorates to become a single entity called Nigeria. The name Nigeria was coined by Flora Shaw, who later became the wife of Lord Lugard.

The origin of the establishment of the Nigerian military could be traced to 1863 when a paramilitary unit was formed which was then known as the 'Glover Hausas'. It was named after Lieutenant John Glover, the then Governor of Lagos, after its annexation in 1861 by the British Government. The Glover Hausas metamorphosed into the West Africa Frontier Force (WAFF) in 1889. With the amalgamation of the Southern and Northern Protectorates in 1914, it became the Nigerian Regiment of the WAFF in 1922. The Nigerian Regiment was renamed the Nigerian Military Force in 1956. The ordinance constituting the Nigerian Military Force was promulgated and changed nomenclature to Nigerian Army in 1960. The Nigerian Army became fully indigenous in 1963 in the wake of Nigeria's attainment of Republican status via the Army Act of 1963. The Nigerian Navy and Nigerian Air Force were established via an Act of Parliament in 1958 and 1964 respectively. After Nigeria attained its independence in 1960, the military continued to be loyal to the first generation of Nigerian politicians until the first military intervention in Nigerian politics via a coup on 15 January, 1966.

The happenings in some post-independence African countries was said to have also encouraged the coup d'état in Nigeria. Some of these included the 23 July, 1952 coup led by Lieutenant Colonel Gamal Abdal-Nasser in Egypt; General Ibrahim Abbond's coup on 17 


\section{Macrothink}

Journal of Public Administration and Governance

ISSN 2161-7104

2021, Vol. 11, No. 2

November, 1958 in Sudan; Colonel Boumedienne's, Algerian Army Chief on 19 June,1965; Congo-Kinshasha's military intervention on 25 November, 1965; Central African Republic's on 1 January, 1966; and Upper Volta's (Burkina Faso) on 3 January, 1966. According to Peretei (2004), 'it was like a wild fire blowing fast across the black continent'.

The coup and countercoup of 1966 began a dismal tradition of military intervention in Nigerian politics. The coups ousted the Balewa's administration and marked the ascendancy of the Nigerian military to the political scene of the country and their concomitant power manipulation and control for also three decades (Zaira, 2013).

The Nigerian state has witnessed eleven coup, counter and abortive coup d'états in her post-independence history.

The table below shows the coup leaders and benefactors, date and nature of the coups.

\begin{tabular}{|l|l|l|l|}
\hline No & COUP LEADER/BENEFACTOR & DATE & NATURE OF COUPS \\
\hline i & $\begin{array}{l}\text { Major Kaduna } \\
\text { Nzeokwu/General J.T.U AguiyiIronsi }\end{array}$ & $\begin{array}{l}15 \text { January, } \\
1966\end{array}$ & Bloody/Successful \\
\hline ii & General Yakubu Gowon & 15 July, 1966 & Counter/Bloody/Successful \\
\hline iii & General Muritala Ramat Mohammed & 29 July, 1975 & Palace/Successful \\
\hline iv & $\begin{array}{l}\text { Colonel B.S. Dimka/General Olusegun } \\
\text { Obasanjo }\end{array}$ & $\begin{array}{l}13 \text { February, } \\
1976\end{array}$ & Bloody/Unsuccessful \\
\hline v & Major General MahummaduBuhari & $\begin{array}{l}31 \text { December, } \\
1983\end{array}$ & Palace/Successful \\
\hline vi & General Ibrahim B. Babaginda & $\begin{array}{l}27 \text { August, } \\
1985\end{array}$ & Palace/Successful \\
\hline vii & Major Gideon GwazaOrkar & 27 July, 1990 & Bloody/Unsuccessful \\
\hline viii & Major General Mamman JiyaVatsa & $\begin{array}{l}17 \text { December, } \\
1985\end{array}$ & Attempted/Abortive \\
\hline ix & General Sani Abacha & $\begin{array}{l}17 \text { November, } \\
1993\end{array}$ & Palace/Successful \\
\hline x & General Oladipo Diya & $\begin{array}{l}21 \text { December, } \\
1997\end{array}$ & Attempted/Abortive \\
\hline xi & General Abdulsalami Abubakar & June, 1998 & Circumstantial \\
\hline
\end{tabular}

Source: Compiled by Author, 2020.

- Bloody coups involved loss of lives.

- Palace coups no loss of lives.

- Attempted/Abortive coups: accused by the Head of State of plotting.

- Circumstantial coup occasioned by the sudden death of the Head of State.

\section{The Crux of Military Rule and Powers of the Head of State}

The first military intervention in Nigerian politics which took place on 15 January, 1966 interrupted the first ever civilian government in the country after independence. The civilian government of independence led by Alhaji Abubakar Tafawa Balewa operated on a written 
constitution. A constitution speaks of the relationship between the government and the governed, how things should be done vis-à-vis the responsibilities of government, the rights of citizens, the economy, foreign policy, intergovernmental relations, among others. The

civilian government had laid down rules and procedures for the governance of the country, regardless of whether the government was good or bad. The first thing military intervention did was to interrupt the flow and pattern of governance in the country. The civilian government which was well known and accepted by the people was abruptly changed on 16 January, 1966 to a brand new system. This new system (military rule) was unfamiliar to the people and the law. It was sudden and arbitrary. The change was never discussed or agreed upon by Nigerians. The new system of governance came through the barrel of the guns and was thrusted on the people. The constitution was suspended and the rule of law changed to rule by decrees designed by the military without the inputs of the people it sought to serve. By suspending the constitution, the military had put aside the modalities and procedures agreed upon by the people to rule themselves no matter their flaws. Under the new system, compliance was a matter of survival not negotiation.

It is imperative to note that under a civilian government, there are contributions from the various organs of government and non-state actors. The civilian government of independence had a President who was a ceremonial Head of State and a Prime Minister as the executive head of government. Also, there was a Parliament which was made up of representatives of the people across the country. Power was not concentrated in any particular level of government.

The main problem with military rule unlike civilian rule is that state power is never exclusive: the power of the State is concentrated in the military Head of State and Commander in Chief of the Armed Forces of the Federation. The military Heads of States were powerful. There are three forms of power concentrated on the military Heads of States: firstly, the sovereign power of the State; secondly, the Commander in Chief of Armed Forces and thirdly, the military Head of State upon assumption of office automatically becomes the most senior officer in the country's Armed Forces. At times, they are promoted as in the case of General Yakubu Gowon. The military Heads of States had enormous powers not because they wanted to rather it was the nature of the military. The military is first and foremost structured and fundamentally authoritarian in nature. The Head of State decides the course and pattern of governance. This is not so because soldiers want to be dictators rather, it is the nature of the military itself. The military is not democratic in nature. These were the kind of situations the country found itself in all the years of military rule. It is worthy to mention that all the military governments from 1966 to 1999 had ruling organs called the Military Supreme Councils. The General Babaginda-led military government changed the name to the Armed Forces Ruling Council in 1983 while General Sani Abacha renamed it the Provision Ruling Council in 1993. The Heads of States being the most senior officers are usually the chairmen of the ruling councils and have the last unchallenged say in any discourse. They constitute the councils, decide membership and allocate responsibilities at will. The President under a democratic government lacks such enormous powers of the state. One may then say the Military Ruling Councils were merely ceremonious and advisory bodies because 
disagreement with the Head of State could be seen as mutiny with grievous penalties. This gives us an insight into the operations of the military councils. It means that the Heads of States, under military rule, decided and directed the affairs of the State with little or no inputs from other organs of the State.

In any case, military discussions and decisions take the top-bottom approach. The most senior officer at any parade/meetings have the final say which must be obeyed. The above reveals how governance and policymaking during the military rule in Nigeria was fundamentally impacted by the structure of the military itself.

However, the fact must be stressed that the different military governments operated under different circumstances. Their outlook and dispositions to governance differ from one regime to another. The circumstances that heralded their emergence as military Heads of States and the environments upon which they operated locally and internationally also affected their performance in office. Some were more flexible on issues of governance than others.

\section{Analysis of the Different Military Regimes and Their Peculiarities in Governance}

THE MAJOR GENERAL JOHNSON THOMAS UMUNAKWE AGUIYI-IRONSI'S MILITARY GOVERNMENT (5 JANUARY, 1966-15 JULY, 1966)

The government emerged through a bloody coup led by Major Chukuma Kaduna Nzeogwu on 15 January, 1966. The coup led to the death of prominent political leaders in the country especially of Northern extraction among whom were Alhaji Abubakar Tafawa, the Prime Minister of the country, and Sir Ahmadu Bello, the Governor of the Northern Region. It is important to note that the journey of the military into Nigerian politics was not without a cause. Major Ademoyega (1981) a key player in the 15 January, 1966 coup argued in his book, "Why We Struck" that there was no doubt that 1965 was a year of political gloom throughout Nigeria.' The study does not intend to analyse the root causes of the coup rather it endeavours to lay a foundation that will help address the problems identified by the study. The political crisis in the Western Region, the National Assembly, the disagreement among political actors coupled with the allegations of corruption and nepotism in government amongst other factors triggered military intervention in Nigerian politics.

Major General Aguiyi-Ironsi was not directly involved in the coup. He was invited by the Council of Ministers of the civilian government to take over the leadership of the country and restore peace being the most senior military officer commanding the Nigerian Army. The intentions of the Major General Aguiyi-Ironsi-led military government were clear from the onset of the regime. He called the government an interim government with the sole aim of uniting and restoring peace in the country (Adeniyi, 2010). The administration did have the luxury of time because the country was at the verge of self-destruction occasioned by the overthrown civilian government when he took over as Head of State. He was preoccupied with attempts to restore peace and order to the country. He was travelling around the country when he was assassinated.

It will be absurd to say Major General Aguiyi-Ironsi's military government made no positive impact on the economy and other areas of governance. Due to the situation of things in the 
country, he was burdened with the task of addressing the situation and saving the country from disintegration. One of the major things the regime will always be remembered for was the change of the country's political system to a united centralised system. The regime altered the existing political structure in the country.

THE GENERAL YAKUBU GOWON'S MILITARY GOVERNMENT (15 JULY, 1966-3 JULY, 1975)

General Gowon's emergence as Head of State was through a counter bloody coup andunusual of military practice not being the most senior officer at the time. Brigadier General Ogundipe was the most senior military officer in the armed forces. He was in charge of the country's leadership during the dark phase from 29 July leading to the announcement of the assassination of the Head of State. However, after prolonged consultations within the Supreme Military Council, Lt. Col. Yakubu Gowon emerged as the Head of State and Commander in Chief of the Armed Forces of Nigeria on 1 August, 1966. General Gowon came into office at a time the country was on the verge of a civil war occasioned by the counter coup of 29 July, 1966, which was allegedly carried out by officers from the Northern Region. The regime lasted for nine years which can be periodised into two: the first four years (1966-1970) and the second five years (1970-1975). The country was engaged in a civil war during the first four years. Issues of economy and other areas of governance were non-issues. The survival of the Nigerian State as a single indivisible entity was paramount. From 1970, survival was no more an issue, rather, national reconciliation and development became the focal point of the administration. The regime had lots of money to spend as a result of the rise in fuel price in the international market and high demand of Nigerian oil by the Global West. General Gowon's regime achieved much in terms of development. They built roads, dams, bridges and made electrical installation across major cities in the country. The regime hosted lots of African events and was a strong voice in the fight against Apartheid in South Africa. Nigeria's visibility and impacting the comity of nations was high and felt during the regime.

General Gowon's style of leadership was different from other military Heads of State in the country. He can be referred to as a quintessential dictator. He appointed experienced politicians and knowledgeable nationalists to assist in fixing the country. Chief Obafemi Awolowo was made the Vice Chairperson of the Executive Council. After successfully fighting the civil war without foreign aids, Nigeria was unanimously elected the chair of ECOWAS in its $10^{\text {th }}$ anniversary in Addis Ababa against its tradition. Nigeria sponsored and took up issues on the African continent and bankrolled them. In an attempt to counter the declaration of the Republic of Biafra and prevent the 30-month civil war, the regime split the country into 12 states. One of the regime's lasting legancy is the establishment of the National Youth Service Corps. The General Gowon military government was not free from alleged corruption and mismanagement of the country's economy as revealed by the Great Purge carried out by the successive military government.

THE GENERAL MURTALA RAMAT MOHAMMED/GENERAL OLUSEGUN OBASANJO MILITARY GOVERNMENT (30 JULY, 1975-1 OCTOBER, 1979) 
General Murtala Mohammed became the third military Head of State through a palace coup that ousted the General Gowon administration. The coup became necessary, according to the coupists, after General Yakubu Gowon's government failed to return the country to civilian rule as promised in his independence speech of 1 October, 1972 andalso due to the mismanagement of the country's economy. The General Murtala government came into office at a time the country was rich and the economy power was high enough to do whatever he wanted. He did not last as Head of State even though he had the energy and a clear vision of what to do. Though General Murtala lacked the patience of his predecessor, his administration enjoyed support both home and abroad. The regime carried out major reforms and restructured the country. The restructuring was holistic and comprehensive. Extant literature refer to the restructuring as a clean-up exercise called the Great Purge by the regime. The General Murtala's administration created more states in the country; it increased the number of states from 12 to 19 in 1976. General Murtala had the flood of economy power to execute many projects both in Nigeria and Africa. His administration was short-lived in a bloody aborted coup led by Lieutenant Colonel B.S. Dimka on 13 February, 1976. General Olusegun Obasanjo his deputy took over power as the fourth military Head of State and continued the programmes of the regime to the end. General Obasanjo introduced discipline into the country's workforce through his concept of 'Low Profile' to curb excess spending in government as witnessed under General Yakubu Gowon's regime.

The regime appointed the Constitutional Committee that produced a new constitution and adopted the presidential system of government for the country in 1979. The 1979 Constitution has been a model for subsequent constitutions in the country. On the international scene, General Murtala took the world by storm within a short period of time. Nigeria gained tremendous respect in the comity of nations. The first visit of a sitting American President to sub-Saharan Africa was to Nigeria in 1978. The regime under the leadership of General Obasanjo ensured Britain accepted responsibility for Zimbabwe's independence and supported the liberation of South Africa from the Apartheid Government. For years, Nigeria co-chaired the Commonwealth Eminent Persons' Group on anti-Apartheidism which eventually ended the Apartheid regime in South Africa. The regime hosted the first united intervention conference for Apartheid in Lagos with 123 countries in attendance in 1978. It also hosted the Second World Black and African Festival of Arts and Culture (FESTAC '77) among others. The regime made Nigeria proud and gave her a voice in international politics. General elections were held at various levels across the country as the climax of the administration's five stages transition programme. On 1 October, 1979, the country returned to civilian rule ending the first coming of the military into politics after 13 years. The country witnessed dynamic leadership and actions guided by the overall concern for national interest and consideration for justice, peace and stability under the regime (Peretei, 2004; Adeniyi, 2010; Etebom, 2015; Fawole, interview 2019).

THE MAJOR GENERAL MUHAMMADU BUHARI'S MILITARY GOVERNMENT (31 DECEMBER, 1983-27 AUGUST, 1985)

Major General Muhammadu Buhari emerged the fifth military Head of States and Commander in Chief of the Armed Forces through a palace coup in the midst of economic 
crisis and political uncertainty in the country. The ousted civilian government of Alhaji Shehu Shagari had spent recklessly, milked and looted the country's economy dry. The civilian government mismanaged and looted the economy such that, when the Buhari - led military administration took over governance, it met an almost empty national treasury. The price of oil had dropped in the international market and the economy was in a very bad shape coupled with the political crisis in the country, especially in the Southwest. The military was forced to engage in countertrade (a form of barter transaction) with some European countries. Nigeria was trading its oil in large quantities in exchange for essential materials such as food, clothes, drugs among others. This partly accounted for why the Major General Buhari's military administration did not do well in the area of economy, not taking away his draconian style of leadership.

Major General Muhammadu Buhari was a round-broad military dictator, one of the strongest military dictators the country ever had as Head of State. He had good intentions but his draconian style of leadership negated the good intentions of his regime. He was too rigid on Nigerians, and even on his Supreme Military Council. The regime did not do much in the international scene outside trade and sustaining existing national foreign policy. The military government involved traditional rulers in the affairs of government. He sought for fatherly counsel and inputs from the traditional institutions in the country. The administration decisively changed the existing monetary mechanism by completely changing all currencies in circulation and immediately replacing them with new currencies in 1984. This was a feat previous administrations in the country could not achieve. The administration also introduced some forms of social objectives in the country. Notable among them was the popular 'War Against Indiscipline' launched in March, 1984. It aimed to instill in the minds of Nigerians the noble ideals of national consciousness and mobilise a sense of nationality (Adeniyi, 2010). The regime will also be remembered for the harsh provisions of Decrees Number 4 and 13. There were high level and gross abuse of human rights under the Buhari-led military administration. However, the inflexible style of discipline and high-handedness, coercion and arbitrariness of the administration led to its being ousted in a palace coup code named 'the Coup of the Generals' which saw only the Head of State and his Deputy/Chief of Staff, Major General Tunde Idiagbon removed from office on 27 August, 1985. It is on record that Major General Buhari's emergence as Head of State was the most heralded in the history of military rule in the Nigeria.

THE GENERAL IBRAHIM BADAMOSI BABANGIDA'S MILITARY PRESIDENCY (27 AUGUST, 1985-17 NOVEMBER, 1993)

General Ibrahim Babangida's emergence as the sixth Head of State through another palace coup was received with mixed feelings among Nigerians. The emergence of his predecessor was understandably greeted with enthusiasm because of the bad state of the nation's economy occasioned by the ousted civilian government of Alhaji Shagari. Nigerians became worried due to the abrupt nature of military intervention in the governance of the country since independence in 1960. General IBB, as he was fondly called, was a warm, calm and gentle leader who understood the Nigerian populace and knew what they wanted at the time. He was not a dictator par excellence like General Buhari. He made lots of friends home and abroad 
and was loved by Nigerians because of his policy and disposition to governance. He came into office when the country's economy was picking up. Upon arrival, General Babangida, having sensed the tension in the country, swiftly came up with a populist agenda that directly touched on the basic rights and socio-economic needs of the people. He claimed to have put in place a transition programme. He got the support of the Nigerian elite and the international community.

General Babangida told the world that his led military government would be the last to rule Nigeria. The administration renamed the Supreme Military Council to the Armed Forces Ruling Council and abrogated to himself the title, Military President. The regime put in place several measures and established national agencies to address the various socio-economic challenges confronting the country. Some of these measures and agencies include: the National Directorate of Employment; the National Directorate of Food, Roads and Rural Infrastructure; Structural Adjustment Programme (SAP); the Directorate of Social Mobilisation (The popular MEMSER policy); the National Electoral Commission; the Constitutional Review Committee that produced the 1989 Draft Constitution and other laudable policies and agencies.

It is imperative to note that the General Ibrahim Babangida's regime had a clear vision of governance and the will to implement its programmes. The military government built the famous Third Mainland Bridge in Lagos, created 11 more states which increased the numbers of states in the country to 30 . He promulgated his official title from Military Head of State to Military President (the first and only Nigerian Military President). He created the State Security Service (SSS), the National Intelligence Agency (NIA), the Defence Intelligence Agency (DIA) and established the Federal Road Safety Corps (FRSC). The regime dualised major roads across the country and built dams. Another notable achievement of the General Babangida's regime was the relocation of the Federal Capital Territory from Lagos to Aso Rock, Abuja. He strengthened Nigerian foreign relations, rejected Apartheid in South Africa, supported and co-sponsored the formation of African Union, made Nigeria join the Organisation of Islamic Cooperation and lots more. The regime had its fair share of human rights abuse; notable are the alleged killing of Dele Giwa with a letter bomb and the killing of his friend and colleague, General Mamman Jiya Vatsa for alleged coup attempt.

The regime, despite its modest achievements, unfortunately, had the longest transition programme in the history of the country. This led to the collapse of the third republic in 1993. The transition programme began its tortuous journey from the third quarter of 1986 and was terminated the third quarter of 1993. The transition programme and dates were changed four times by the military regime. The government established two political parties in the country: the Social Democratic Party (SDP) and the National Republican Party (NRC). Elections for Local Government Councils across the country, the State Houses of Assembly, National Assembly and the Governors were successfully conducted. The Presidential election which was the climax of the transition programme was annulled on 12 June, 1993 by the military government. The elections were adjudged to be free and fair by both local and international election observers. General Ibrahim Babangida stepped aside (in his words) on 27 August, 1993 in response to pressure and protest arising from the annulment of the Presidential 
election. He handed over to an Interim Civilian Government headed by Chief Ernest Shonekan.

THE GENERAL SANI ABACHA'S MILITARY GOVERNMENT (17 NOVEMBER, 1993-8 JUNE, 1998)

General Sani Abacha took over power from the Interim National Government in a palace coup on 17 November, 1993. He renamed the General Ibrahim Babangida's Armed Forces Ruling Council to Provisional Ruling Council. It was an open secret that General Abacha had been involved in the previous successive coup d'état in the country. He made the national broadcast of the change of government from civil rule to military in 1983 and also announced the counter coup of August 1985 that ousted the General Buhari's Military Government. He was the only senior military officer and member of the General Babangida's Military Council not retired when the military President stepped down from government in 1993. His Provisional Ruling Council consisted of six senior military officers, the Inspector General of Police and four civilians. The Council of Ministers under the General Abacha Military Government had 32 members out of which 30 were civilians. The political environment home and abroad was tensed when he assumed the leadership of the country. This was occasioned by the annulment of the 12 June, 1993 Presidential election.

The new military government began by the introduction of War Against Indiscipline and Corruption. It was not surprising the same government turned out to be one of the most corrupt military government with the Abacha loots discovery years after his demise. General Sani Abacha had a different style of leadership. He was mean and not known for ideas or philosophy. He was a blunt dictator. In 1994, he issued a decree that placed his military government above the jurisdiction of any court in the country (Adeniyi, 2010; Zaira, 2013). He abrogated absolute power to himself as the Commander-in-Chief of the Armed Forces. He could detain anyone without trial for up to three months. Chief M.K.O.Abiola, the acclaimed winner of the 12 June, 1993 Presidential election, declared himself President of the Federal Republic of Nigeria. He was arrested at the orders of the Head of State for treason, jailed and subsequently died in detention. The trio of General Olusegun Obasanjo, General ShehuYar'Adua and General Oladipo Diya were arrested for alleged coup attempt and jailed; General Shehu Yar'Adua died in detention also. The military government of General Abacha tolerated no opposition; he was a dictator par excellence. Since he understood the coup game, he cracked down on all perceived enemies of his government and policy within and outside the military. The height of the regime's human right abuse was the killing of Ken Saro Wiwa and other Ogoni activists despite the outcry from within the country and abroad. Another gruesome human right abuse the regime was accused of was the alleged murder of Alhaja Kudirat Abiola, the wife of the acclaimed winner of the 1993 Presidential election, for her continuous protest against the government. Nigeria became a pariah state under the General Abacha's regime. The international community closed her doors against Nigeria for the four and half years of General Sani Abacha's reign as Head of State.

The administration did well in the economy, it reduced the external debts from 36 billion dollars in 1993 to 27 billion dollars in 1997. The administration also increased the country's 
foreign reserve from 4.4 billion dollars to 9.6 billion dollars within the same period (Adeniyi, 2010). The unprecedented economic achievements of the regime were overshadowed years later by the discovery of mass looting of the national treasury and corruption by the Head of State. Twenty-two years after the demise of General Sani Abacha, the country, through the successive civilian governments, is still recovering Abacha's loots from banks around the world.

The military government of General Abacha created six states, taking the numbers of the states in the country to 36 . The administration also reorganized the country into 6 geopolitical zones. The government established and funded five political parties as part of its transition programme. He announced the transition programme was to begin 1 August, 1998 and terminated with the Presidential election and a return to civilian rule on 1 October, 1998. General Abacha manipulated the political system and was adopted by all the five political parties as their sole presidential candidate for the 1998 presidential election. He died on 8 June, 1998 before the transition programme commenced.

THE GENERAL ABDULSALAMI ABUBAKAR'S MILITAY GOVERNMENT (8 JUNE, 1998-29 MAY, 1999)

General Abdulsalami Abubakar emerged the eighth military Head of State after the sudden death of General Abacha on 8 June, 1998. General Abdulsalami was a gentleman officer whom the responsibility of the country's leadership fell upon, although he was the number three man in the military hierarchy at the time. The number two man next to the late Head of State, General Oladipo Diya, was in detention for an alleged coup attempt. General Abdulsalami was not known, all his days in the military, to have had political ambitions or held any political position. Till date, he is the only former military Head of State in Nigeria that has not sought for political office after retirement. His emergence as Head of State was received with great enthusiasm home and abroad. This was occasioned by the gross human right abuse and the failed succession plan of late General Sani Abacha. The International community had already closed its doors on Nigeria as a pariah State. General Abdulsalami made it clear from the outset of his regime that he was ready to return the country to civilian rule within a short period of time. He also promised that his military-led government would be the last and soldiers would be returned to the barracks to focus on their constitutional duty. The international community opened her doors to the country and Nigeria reclaimed her position and respect in the comity of nations. General Abdulsalami did not pay much attention to the economy, he was preoccupied with the transition plans. He got the support of the world and within three months as Head of State, he had visited Great Britain, the United States of America, Canada and Israel, a feat General Sani Abacha could not achieve in four and half years in office. General Abacha only visited South Africa during President Mandela's inauguration while in office. General Abdusalami successfully executed his transition programme within eleven months and returned the country to democratic rule on 29 May, 1999 after 16 years of successive military rule in the country.

\section{Post-Military Era: The Fourth Republic}

The influence of the military is expectedly still felt in all facets of governance in the country. 
When the country returned to democratic rule in 1999, the military had been in charge for 29 years out of the 39 years of its existence as an independent entity. Furthermore, the second coming of the military lasted for 16 uninterrupted years. All these years of influence cannot be wished away. Most of the political elite in the fourth republic cut their political tooth during the military regime. This, to a large extent, has affected their political orientation and disposition to politics.

The military elite accumulated a lot of wealth during their long stay in government. Adekanye (2003) argued that in 1999, when the country returned to civil rule, all the senior officers and Generals retired by President Olusegun Obasanjo were young millionaires. At the time President Obasanjo retired the military officers who held political offices or served during the military era, most of the retired officers were in their forties and fifties. They could not sit down and watch the polity doing nothing. They had interests to protect and it would be difficult to achieve that outside politics. While some went into business, others saw politics as an avenue to further exert their influence. They joined politics, contested, sponsored candidates and bankrolled elections. The military was largely responsible for the emergence of General Olusegun Obasanjo as President in 1999. From 1999 till date, retired military officers have been actively involved in Nigeria's politics. The military has produced Governors (Prince Olagusoye Oyinlola, Osun State; Jonah Jang, Plateau State), Senators (Senator David Mark, a two term Senate President), Ministers, amongst others. They are playing major roles in business, politics, nation building and peace in the country. The retired military officers have also held sway for 14 years out of the current 21 years in the Fourth Republic. (Etebom, Ihemeje \& Fagbohun, 2014) The influence of the retired military will continue to be felt on the Nigerian political scene for a while; although, their influence will wane and fade off with time. This will be so because most of the influential retired military officers and former military leaders are leaving the political stage due to age and eventually, death will come at different times. The Nigerian political space will then be open to those whose lives and wealth have nothing to do with the military rule. It is imperative to mention that retired military officers, like other citizens, will continue to participate in the country's politics but will not command much influence and wealth like the former Heads of State and political office holders during military rule. It is not likely to have another former Head of State contest for Presidency after General Buhari's tenure in 2023. The two most important roles being played by the military elite in the democratic process of the fourth republic has been participatory and advisory beside its constitutional obligation.

\section{Conclusion and Recommendations}

The long years of military rule in Nigeria and their impact cannot be wished away. The almost three decades of post-independence, during which the military controlled the dynamics of the country defined and shaped the political orientation of the political elite, and also laid the foundation for national interaction and development. It will be absurd to take a definitive position on the long years of military rule in the country. Also, it will be a narrow assertion to draw conclusions based on a regime or an aspect of governance as espoused in the study. 


\section{Mll Macrothink}

There were areas the military were adjudged to have done fairly well, like infrastructural development, state creation and security. Some military governments even performed quite well in economy, foreign policy, among others. In foreign policy, the military made the country proud and gave her a voice in the comity of nations with the exception to the General Abacha's administration. The military could have done more in infrastructural development. In the same vein, the records of the military on human right and corruption were awful and their impact is still being adversely felt in the country. It is worthy to note that the military governments were actively assisted by civilians and technocrats in running the affairs of the country. They helped in the formulation and implementation of policy which shaped and defined governance in the country at all levels under military rule.

Military rule in Nigeria was a whole mixed bag. The political and economic situation both home and abroad at the time shaped and influenced the various military governments. The disposition of the Heads of State to life and governance was also a major factor under military rule. Although military rule fundamentally disrupted the country's political system and process, its place in Nigerian historical development cannot be overemphasised because of its impact and long stay in power.

The study strongly recommended that the political class and elites should not allow a repeat of the country's experience between 1979 and 1983 that led to the second coming of the military in politics. The socio - economic challenges confronting the country should be objectively addressed with emphasis on the alarming rate of insecurity and unemployment in the country.

\section{References}

Ademoyega, A. (1981). Why We Struck: The Study of the first Nigeria Coup. Evans. Ibadan.

Adeniyi, P. (2010). Nigeria: Yesterday, Today and Tomorrow. Daily Graphics Nigeria Limited. Ibadan.

Adekanye, J. B. (2003). The Retired Military as Emergent Power Factor in Nigeria. Heinemann Educational Book, Nigeria.

Agagu, A. A., \& Ola, R. F. (2011). Development Agenda of the Nigerian State. (ed). Lord Keynes Publishing Company, Akure.

Etebom, J. M. (2015). Retired Military Officers and Democratic Process in Nigeria; Unpublished M.Sc Thesis, Obafemi Awolowo University, Ile-Ife.

Etebom, J. M, Ihemeje, G., \& Fagbohun, F. O. (2014). The Retired Military Elites and Nigeria's $4^{\text {th }}$ Republic: 1999-2014. Ife Journal of International Affairs, 2(2).

Ekeh, P. (1998). Theory and Curse of Military Ruke and the Transition Program: University of Buffalo, New York.

Finer, S. (1969). The Man on the Horse Back. London: Fall Mall. 
Huntinton, S. (1968). Political Order in Changing Societies. New Haven; Yale University Press.

Peretei, I. K. (2004). Military Adventurism in Nigerian Politics. Mentors Communication, Abuja.

Zaira, N. R. J. (2013). Nigerian Military in Politics; 1966-2011. Ahmadu Bello University Press Ltd, Zaria.

The 1999 Constitution of the Federal Republic of Nigeria with Amandments 2011. Ahmadu Bello University Press, Zaria.

\section{Copyright Disclaimer}

Copyright for this article is retained by the author(s), with first publication rights granted to the journal.

This is an open-access article distributed under the terms and conditions of the Creative Commons Attribution license (http://creativecommons.org/licenses/by/4.0/). 